\title{
Hematodinium sp. and its bacteria-like endosymbiont in European brown shrimp (Crangon crangon)
}

\author{
Grant D Stentiford $^{1 *}$, Kelly S Bateman ${ }^{1}$, Hamish J Small ${ }^{2}$, Michelle Pond ${ }^{1}$ and Anette Ungfors ${ }^{3}$
}

\begin{abstract}
Background: Parasitic dinoflagellates of the genus Hematodinium are significant pathogens affecting the global decapod crustacean fishery. Despite this, considerable knowledge gaps exist regarding the life history of the pathogen in vivo, and the role of free living life stages in transmission to naïve hosts.

Results: In this study, we describe a novel disease in European brown shrimp (Crangon crangon) caused by infection with a parasitic dinoflagellate of the genus Hematodinium. This is the second example host within the Infraorder Caridea (shrimp) and significantly, the first description within the superfamily Crangonoidea. Based upon analysis of the rRNA gene (SSU) and spacers (ITS1), the parasite in C. crangon is the same as that previously described infecting Nephrops norvegicus and Cancer pagurus from European seas, and to the parasite infecting several other commercially important crab species in the Northern Hemisphere. The parasite is however distinct from the type species, H. perezi, found infecting type hosts (Carcinus maenas and Liocarcinus depurator) from nearby sites within Europe. Despite these similarities, the current study has also described for the first time, a bacteria-like endosymbiont within dinospore stages of the parasite infecting shrimp. The endosymbionts were either contained individually within electron lucent vacuoles within the parasite cell cytoplasm, or remained in direct contact with the parasite cytoplasm or in some cases, the nucleoplasm. In all of these cases, no apparent detrimental effects of colonization were observed within the parasite cell.

Conclusions: The presence of bacteria-like endosymbionts within dinospore life stages presumes that the relationship between the dinoflagellate and the bacteria is extended beyond the period of liberation of spores from the infected host shrimp. In this context, a potential role of endosymbiosis in the survival of free-living stages of the parasite is possible. The finding offers a further intriguing insight into the life history of this enigmatic pathogen of marine crustacean hosts and highlights a potential for mixotrophy in the parasitic dinoflagellates contained within the genus Hematodinium.
\end{abstract}

Keywords: ITS1, Phylogenetics, Dinoflagellate, Bacteria, Crustacean, Disease, Fishery

\section{Background}

Parasitic dinoflagellates of the genus Hematodinium are considered some of the most significant known pathogens affecting commercially exploited global decapod crustacean fisheries [1]. Recent reviews [1-3] indicate a wide host range, mainly across several superfamilies of the Brachyura (Portunoidea, Cancroidea, Calappoidea,

\footnotetext{
*Correspondence: grant.stentiford@cefas.co.uk

'European Union Reference Laboratory for Crustacean Diseases, Centre for Environment, Fisheries and Aquaculture Science (Cefas), Barrack Road, Weymouth, Dorset DT4 8UB, United Kingdom

Full list of author information is available at the end of the article
}

Majoidea and Xanthoidea) but also the infraorders Anomura (subfamily Galatheoidea) and Astacidea (subfamily Nephropoidea). Recently, the host range has been further extended into the infraorder Caridea (subfamily Palaemonoidea) with the description of Hematodiniumlike infections in farmed populations of the palaemonid ridgetail prawn Exopalaemon carinicauda in China [4]. In this first description of a Hematodinium-like dinoflagellate in prawns, the parasite was demonstrated to be likely the same as that causing similar infections in the Chinese swimming crab (Portunus trituberculatus) and mud crab (Scylla serrata) co-cultured in these farms

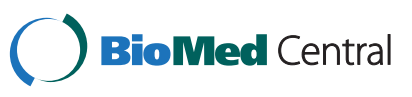


$[5,6]$, suggesting that the parasite may be a host generalist, a point elaborated in recent studies $[7,8]$. Hematodiniumlike dinoflagellates have also been reported from a number of non-decapod crustaceans, namely members of the superorder Peracarida, order Amphipoda, although in most of these cases, molecular diagnosis and subsequent phylogenetic analysis was not carried out [9]. Small et al. [10] have demonstrated that at least one species, the crustacean carrion scavenging lysianassid amphipod Orchomene nanus was associated with a parasite with $98 \%$ identity (ITS1 rRNA partial sequence) to the Hematodinium sp. infecting Nephrops norvegicus from the same fishing grounds. Likewise Pagenkopp Lohan et al. [8] also report detecting Hematodinium DNA within Caprellid amphipods from estuaries from the east coast of the United States.

A study by Small et al. [11] focussed on characterizing the recently discovered type species, Hematodinium perezi, infecting one of the type hosts, Liocarcinus depurator, collected from near to the type location (English Channel, Europe). In that study, comparison of the ITS rRNA region sequences between the type species and others in GenBank revealed three distinct $H$. perezi genotypes infecting several portunid hosts (e.g. Liocarcinus depurator, Callinectes sapidus, Portunus trituberculatus and Scylla serrata). However, this is not an exclusive host grouping as both $\mathrm{Xu}$ et al. [4] and Pagenkopp Lohan et al. [8] have shown that $H$. perezi is capable of infecting other non-portunid hosts. Analysis of the parasites SSU rRNA gene and ITS regions by Small et al. [11] and others [12-14] suggests that a second, currently unnamed Hematodinium sp. infects a growing number of crustacean host species from the Northern Hemisphere. The latter includes well-documented disease outbreaks in the fisheries for Nephrops norvegicus [15] and Cancer pagurus [16,17] in Europe, and Chionoecetes bairdi, Chionoecetes tanneri and Chionoecetes opilio in Canada and Alaska [3].

In the current study, we describe a Hematodinium sp. parasite infection in wild Crangon crangon from the European fishery. For the first time, the parasite was shown to be colonised by bacteria-like endosymbiont that inhabited the cytoplasm, and occasionally the nucleoplasm of the parasite. Molecular phylogenetic analysis of the parasite from C. crangon suggests it to be the same as that infecting other decapod crustaceans from the Northern hemisphere (e.g. Nephrops norvegicus, Chionoecetes opilio, Cancer pagurus, Carcinus maenas). The findings are discussed in relation to the expanding range of known hosts to Hematodinium dinoflagellate infections and the nature of the relationship with the bacteria-like endosymbiont.

\section{Results}

Visual screening of a subsample of C. crangon from the Wash fishery in July 2010 indicated an apparent prevalence of $1.6 \%(8 / 480)$ of shrimp displaying abnormal opacity and lethargy (Figure 1). Affected shrimp exhibited a loss of carapace transparency and upon opening of the body cavity, contained milky, opaque haemolymph that did not clot. Histological analysis of tissues collected from affected shrimp revealed a systemic infection by a protistan pathogen with a limited, eosinophilic cytoplasm and a distinctive, basophilic nucleus containing condensed chromatin. In several cases, multi-nucleate plasmodial life stages were also observed, the cumulative effect being distension of the haemal sinuses (particularly within the hepatopancreas, where connective tissues and other inter-tubular tissues were apparently limited) (Figure 2A and B). The pathognomonic signs were typical of previous descriptions of Hematodinium spp. infections in crustacean hosts. Haemocyte encapsulation responses were not observed in any of the infected shrimp assessed though haemocytes were occasionally observed amongst the massed parasite cells. In all cases, the hepatopancreas of shrimp assessed using histopathology were co-infected with Crangon crangon bacilliform virus $(\mathrm{CcBV})$, previously described in European $C$. crangon populations [18,19]. In most shrimp, CcBVinfected epithelial cells were widely distributed throughout the organ (Figure 2C). In a manner consistent with Hematodinium sp. reported infecting other decapod hosts, the ovary of infected female shrimp was apparently arrested in pre-vitellogenic development. In addition, oogonia (early development stages of the ovarian lineage) were often apoptotic (Figure 2D). The skeletal musculature of infected shrimp was atrophied and contained enlarged haemal sinuses containing masses of parasite cells (Figure 2E). Filamentous trophont stages of the parasite were apparently

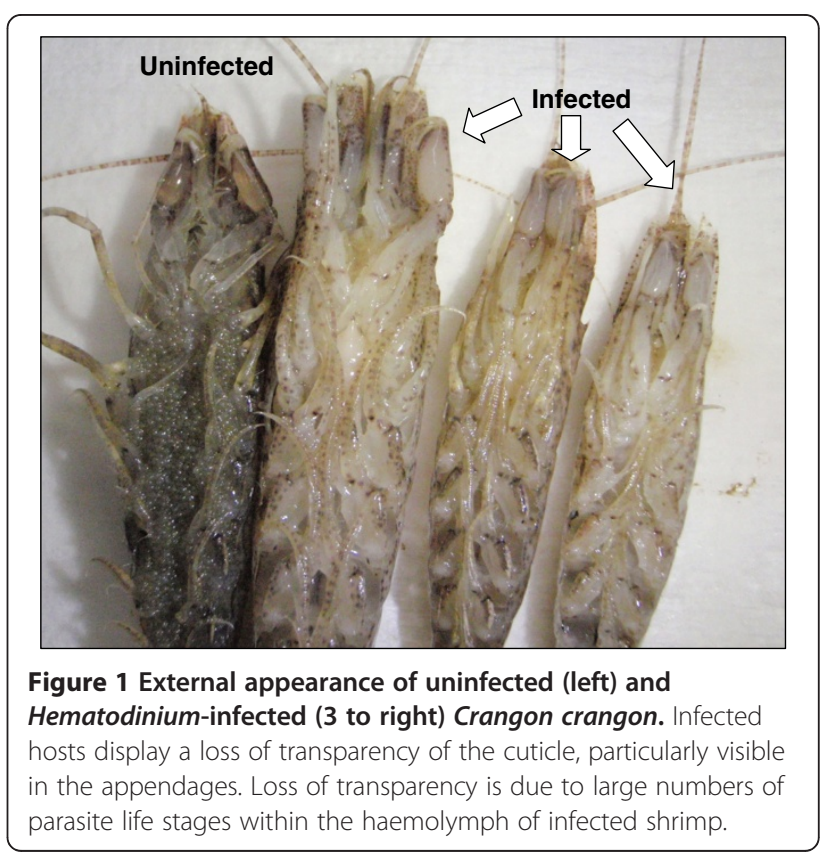



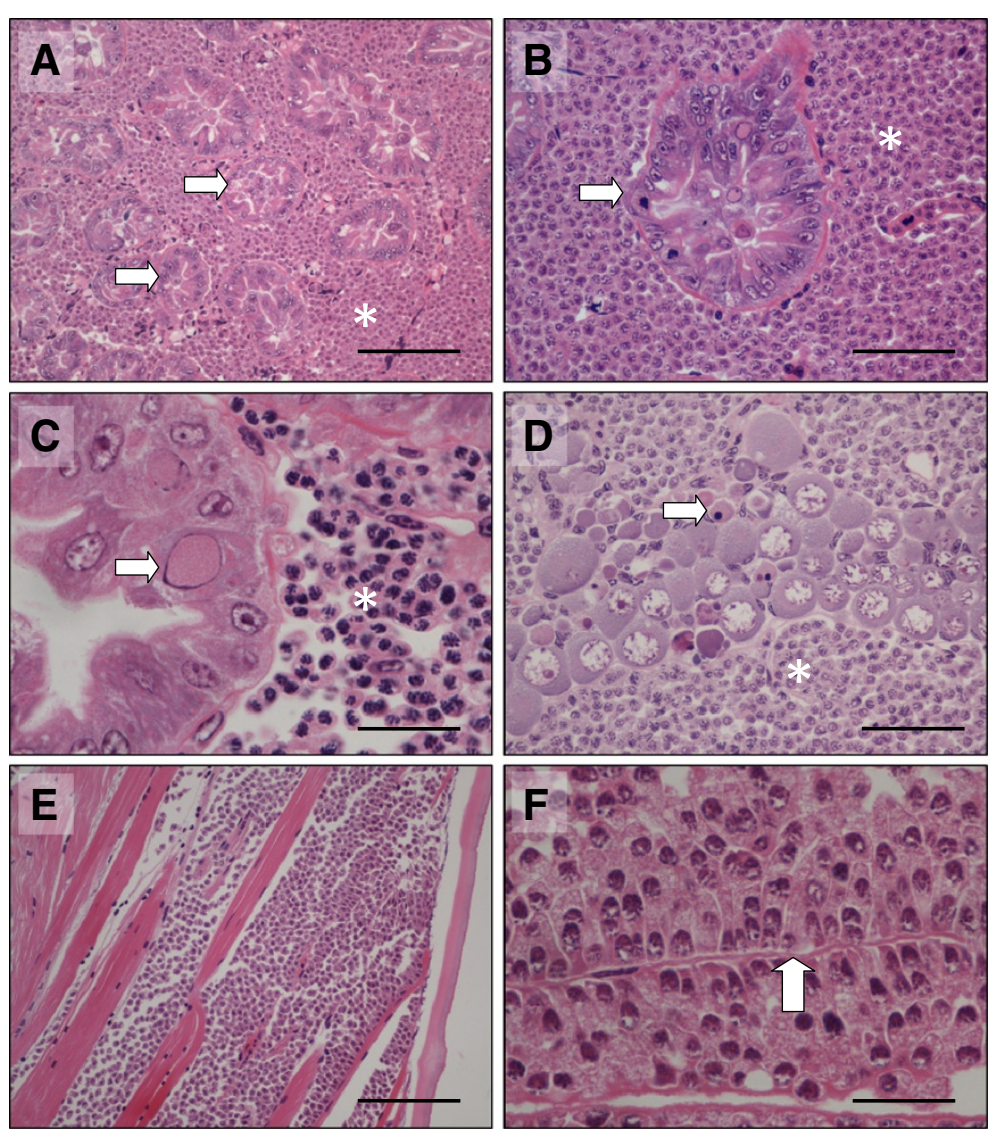

Figure 2 Histopathology of Hematodinium sp. infection in Crangon crangon. (A) Low power image showing distension of hepatopancreatic haemal sinuses with masses of Hematodinium sp. parasites (asterisk). Hepatopancreatic tubules are shrunken and are depleted of lipid inclusions (arrows). Scale $200 \mu \mathrm{m}$. (B). Single hepatopancreatic tubule (arrow) surrounded by masses of Hematodinium sp. parasitic life stages (asterisk) within the distended haemal sinuses. Scale $100 \mu \mathrm{m}$. (C) Hepatopancreatic tubule co-infected with Crangon crangon bacilliform virus (CcBV) (arrow) (Stentiford et al. 2004). Hematodinium sp. parasite life stages are seen within the haemal sinuses (asterisk) Scale $50 \mu m$ (D). Ovary, apparently arrested in pre-vitellogenic status. Oocytes do not contain vitellogenesis and oogonia are often apoptotic (arrow). Parasite life stages are in direct contact with oocytes (asterisk). Scale $100 \mu \mathrm{m}$. (E). Skeletal musculature within a walking appendage. Atrophy of muscle fibres is accompanied by colonisation of haemal spaces with masses of parasite cells. Scale $200 \mu \mathrm{m}$. (F). Attachment of filamentous trophonts to remnant basement membranes (arrow) within the atrophied skeletal musculature. Scale $25 \mu \mathrm{m}$. All images H\&E histology.

attached to remnants of the basal membrane or sarcolemma of atrophied muscle fibres (Figure 2F).

Transmission electron microscopy (TEM) revealed that the haemolymph and tissues of $C$. crangon harboured trophont (Figure 3A and $\mathrm{C}$ ) and dinospore (Figure 3B) stages of a parasitic dinoflagellate parasite with features largely consistent with Hematodinium spp. previously described infecting other marine crustacean hosts. Trophonts contained trichocysts, mitochondria, large electron lucent vacuoles, and a distinctive surrounding alveolar membrane (Figure 3A). Trichocysts were defined by an electron dense, cuboid laminar core surrounded by a trichocyst sac, terminating with a distinctive pusular sac. In several instances, the pusular sac was closely opposed to the inner cell membrane of the parasite (Figure 3D). Structures resembling the micropores of apicomplexans were observed in several trophonts (Figure 3E). Spore stages were defined by the presence of flagella contained beneath the outer layer of the alveolar membrane and displaying a $9+2$ arrangement of microtubules (Figure 3F).

In a manner not previously observed for the Hematodinium spp. dinoflagellates, dinospore life stages (Figure 3B and $\mathrm{C}$ ), accommodated numerous bacterialike endosymbionts (Figure 4A). Bacteria-like cells were either contained individually within electron lucent vacuoles within the parasite cell cytoplasm (Figure 4A; see also Figure $3 \mathrm{~B}$ ), or remained in direct contact with the parasite cytoplasm (Figure $4 \mathrm{C}$ ) or in some cases, the nucleoplasm (Figure 4B; see also Figure 3C). In the case of those in direct contact with the cytoplasm, bacterialike cells were occasionally observed undergoing fission (Figure 4C). In all cases where bacteria-like cells were observed within individual parasite cells, the ultrastructure of the parasite cell appeared otherwise normal when 

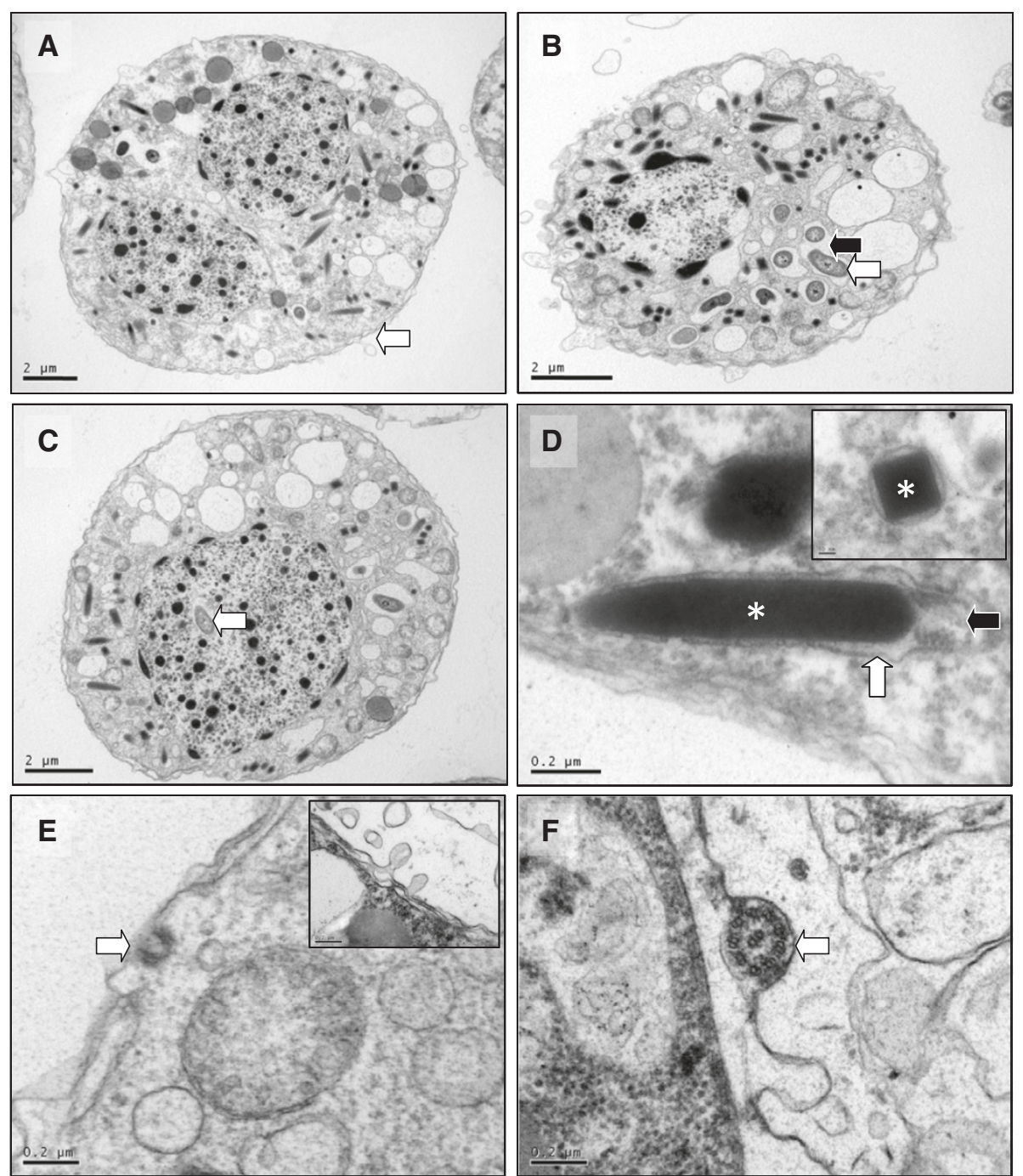

Figure 3 Ultrastructure of trophont and spore stages of Hematodinium sp. from Crangon crangon. (A) Bi-nucleate trophont containing trichocysts $(T)$, mitochondria $(M)$, vacuoles $(V)$, Lipid Droplets $(L)$ and a surrounding alveolar membrane (white arrow). (B) Dinospore with similar features to A. but with additional presence of numerous bacteria-like symbionts within the parasite cytoplasm (arrows). Bacteria-like symbionts appear to reside in an electron lucent vacuole (black arrow). (C) Dinospore with similar features to B but with additional presence of bacteria-like symbionts within the parasite nucleoplasm (arrow). (D) Detail of trichocyst within the parasite cytoplasm. The electron dense laminar core (asterisk in main image and inset) is surrounded by the trichocyst sac (white arrow) that terminates at the pusular sac (black arrow). (E) Detail of apicomplexan-like micropore (arrow) and blebbing of alveolar membrane surrounding the trophont (inset). (F) Flagella of dinospore stage displaying classic $9+2$ arrangement of microtubules (arrow).

compared to parasite cells without bacteria-like endosymbionts. Although we cannot discount the presence of bacteria-like cells within trophonts, all observed cases were associated with dinospore life stages.

Analysis of the amplified rRNA fragments (containing the partial 3' end of the SSU gene and ITS1 region) confirmed that the parasite infecting $C$. crangon was a Hematodinium spp. Twenty two of the thirty clone sequences of the partial SSU sequence fragment (177 bp-immediately upstream of the SSU/ITS1 border) were identical, and the others differing from this common allele only by the presence of single nucleotide polymorphisms (SNP, $\mathrm{n}=7$ ) or by two SNPs $(\mathrm{n}=1)$ within each clone sequence. BLAST analysis of the common SSU allele resulted in a $100 \%$ similarity to SSU sequences in GenBank for the Hematodinium sp. infecting Nephrops norvegicus (FJ844429), Chionoecetes angulatus (FJ844426), Chionoecetes tanneri (FJ844424), Chionoecetes opilio (FJ844422), Chionoecetes bairdi (FJ844417), Carcinus maenas (EF675765), Cancer pagurus (DQ871211), Pagurus bernhardus (DQ871213), and other hosts. The ITS1 region sequences differed in length (between 327 and $335 \mathrm{bp}$ ), even among clone sequences generated from the same genomic DNA samples. This was due to a number of 


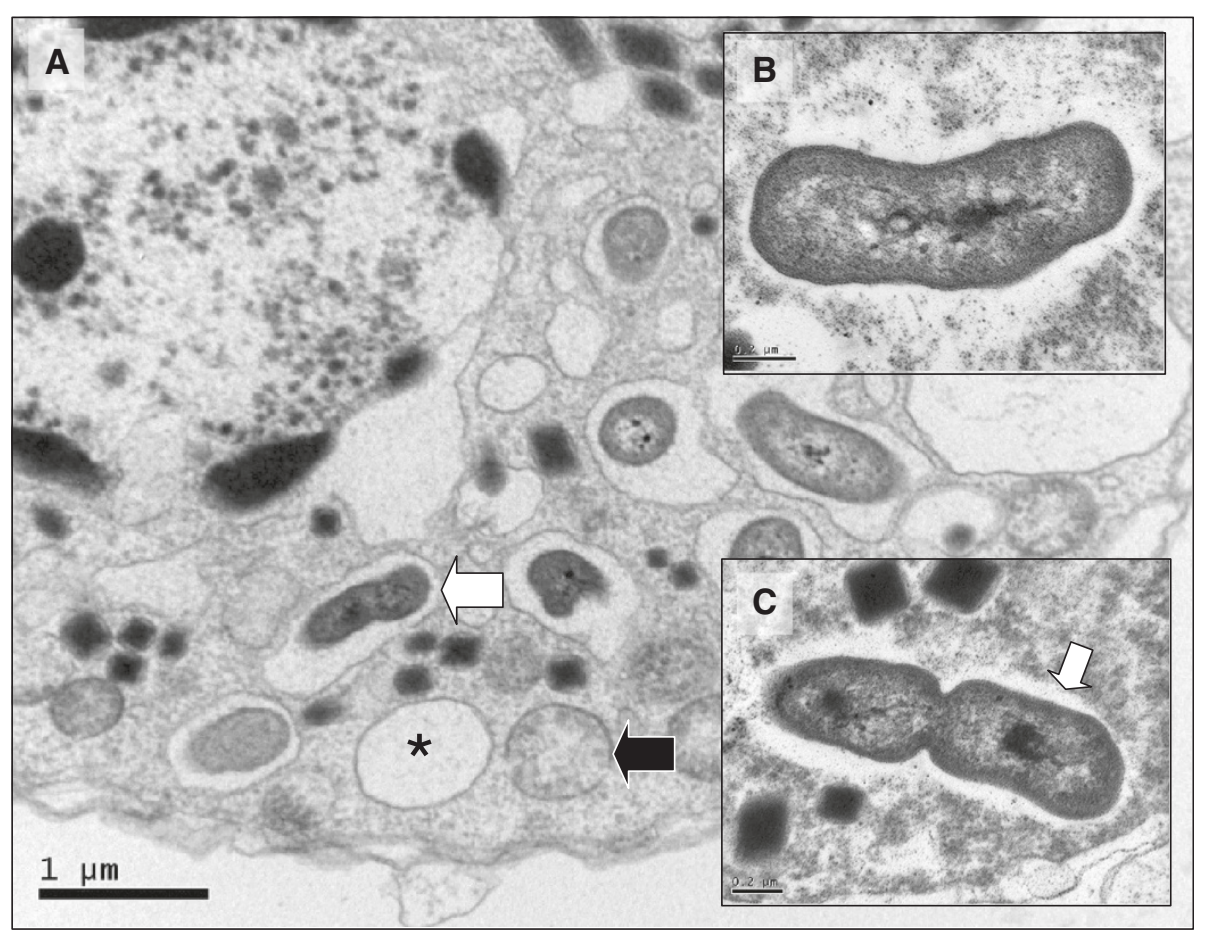

Figure 4 Ultrastructure of bacterial symbiont within dinospore of Hematodinium sp. from Crangon crangon. (A) bacteria-like symbionts generally occupied electron lucent vacuoles within the spore cytoplasm of the majority of individual parasites observed (white arrow). Empty electron lucent vacuoles (asterisk) and mitochondria (black arrows) were seen in close proximity to endosymbionts. (B) Single bacteria-like symbiont within the nucleoplasm of the parasite (as shown in Figure 3C). Note the apparent absence of the electron lucent vacuole generally seen surrounding bacteria-like symbionts occupying the cytoplasm. (C) Dividing endosymbiont within the cytoplasm of the parasite cell. Note in this case, the endosymbiont was not surrounded by a vacuolar membrane buy instead lay in direct contact with the host cytoplasm, albeit surrounded by an electron lucent halo (arrow).

repetitive motifs previously described in the ITS regions of this Hematodinium sp. [13,20,21]. A number of SNPs were also observed. Eight of the 30 ITS1 sequences were identical. BLAST analysis of this common ITS1 allele resulted in a $100 \%$ similarity to ITS1 sequences in GenBank for the Hematodinium sp. infecting Chionoecetes opilio from Canada (FJ844422) and Greenland (FJ172640), Lithodes couesi (FJ844413), Liocarcinus depurator from Denmark (FJ172661), Nephrops norvegicus from Denmark (FJ172658) and Scotland (DQ871212), Pagurus bernhardus from Denmark (FJ172637) and Scotland (FJ495188), Hyas araneus from Greenland (FJ172644), and 99\% similar to additional sequences from the above hosts and to Cancer pagurus from Scotland (DQ871211) and Ireland (EF031998). Three of the remaining ITS1 sequences were also identical and differed from those in GenBank from Chionoecetes opilio, Lithodes couesi, Liocarcinus depurator, Nephrops norvegicus, Pagurus bernhardus, and others by a single base deletion. The remaining 19 ITS1 sequences were unique, however these differed from those in GenBank by a single SNP $(\mathrm{n}=9)$, or by a combination of SNPs and insertions/deletions of repetitive motifs. The partial SSU and complete ITS1 rRNA sequences from the Hematodinium sp. infecting $C$. crangon have been deposited in GenBank with accession numbers JX499154- JX499183.

\section{Discussion}

Parasitic dinoflagellates comprising the genus Hematodinium have been described in over 40 crustacean host taxa [1]. These descriptions include infections of hosts across two Superorders (Pericarida and Eucarida) of the Subclass Eumalacostraca (Class Malacostraca). Within the Eucarida, all host taxa described to date reside within the Order Decapoda, Suborder Pleocyemata. Within the Pleocyemata, Hematodinium sp. parasites have been described infecting hosts from the Infraorders Caridea, Astacidea, Anomura and Brachyura. To date, the majority of descriptions relate to hosts residing within the Brachyura, possibly due to the fact that the large, commercially fished crab species are contained within this Infraorder and have thus received most attention as part of field surveys. A summary of host range across the Class Malacostraca is provided in Figure 5. In addition to the widely divergent (and likely underreported) host range, infection by parasitic dinoflagellates of the genus Hematodinium have been reported in crustacean from across the globe, encompassing host species 


\section{Subphylum Crustacea Brünnich, 1772}

Class Branchiopoda Latreille, 1817

Class Remipedia Yager, 1981

Class Cephalocarida Sanders, 1955

Class Maxillopoda Dahl, 1956

Class Ostracoda Latreille, 1802

Class Malacostraca Latreille, 1802

Subclass Phyllocarida Packard, 1879

Subclass Hoplocarida Calman, 1904

Subclass Eumalacostraca Grobben, 1892

Superorder Syncarida Packard, 1885

Superorder Peracarida Calman, 1904 Order Amphipoda Latreille, 1816

Suborder Gammaridea Latreille, 1802

Family Ampeliscidae Costa, 1857

Family Aoridae Walker, 1908

Family Haustoriidae Stebbing, 1906

Family Lysianassidae Dana, 1849

Family Melitidae Bousfield, 1973

Family Melphidippidae Stebbing, 1899

Family Oedicerotidae Lilljeborg, 1865

Family Phoxocephalidae Sars, 1891

Family Phoxocephalopsidae Barnard \& Drummond, 1982

Superorder Eucarida Calman, 1904

Order Euphausiacea Dana, 1852

Order Amphionidacea Williamson, 1973

Order Decapoda Latreille, 1802

Suborder Dendrobranchiata Bate, 1888

Suborder Pleocyemata Burkenroad, 1963

Infraorder Stenopodidea Claus, 1872

Infraorder Caridea Dana, 1852

Superfamily Palaemonoidea Rafinesque, 1815

Family Palaemonidae Rafinesque, 1815 (1)

Superfamily Crangonoidea Haworth, 1825

Family Crangonidae Haworth, 1825 (1, this study)

Infraorder Astacidea Latreille, 1802

Superfamily Nephropoidea Dana, 1852

Family Nephropidae Dana, 1852 (1)

Infraorder Thalassinidea Latreille, 1831

Infraorder Palinura Latreille, 1802

Infraorder Anomura MacLeay, 1838

Superfamily Galatheoidea Samouelle, 1819

Family Galatheidae Samouelle, 1819

Family Lithodidae Samouelle, 1819

Family Paguridae Latreille, 1802

Infraorder Brachyura Latreille, 1802

Superfamily Calappoidea Milne Edwards, 1837

Family Calappidae Milne Edwards, 1837

Superfamily Majoidea Samouelle, 1819

Majidae Samouelle, 1819

Oregoniidae, Peter et al. 2008

Superfamily Cancroidea Latreille, 1802

Cancridae Latreille, 1802 (4)

Superfamily Portunoidea Rafinesque, 1815

Portunidae Rafinesque, 1815 (10)

Superfamily Xanthoidea MacLeay, 1838

Hexapodidae Miers, 1886

Menippidae Ortmann, 1893

Panopeidae Ortmann, 1893

Trapeziidae Miers, 1886

Figure $\mathbf{5}$ (See legend on next page.) 
(See figure on previous page.)

Figure 5 Summary of host range to Hematodinium dinoflagellate infections across the Class Malacostraca of the Subphylum Crustacea.

Taxa with representative host species are shown in red. Numbers in parentheses refer to the approximate number of described hosts within a

specific taxonomic group at the time of writing.

from Australian, European, North American, Canadian, Alaskan, Russian and Chinese waters [1]. The pronounced pathology associated with patent disease has led to marketing and fishery consequences for infected hosts and their populations [2]. In this context, the disease associated with Hematodinium sp. infection is considered as a key health issue affecting the sustainability of the global crustacean fishery [22].

Despite this diversity in host, geographic and habitat range, considerable evidence now exists to suggest that two different species of Hematodinium infect the majority of known hosts, at least in the Northern Hemisphere $[1,11,13]$. Data relating to sequencing of the rRNA genes (SSU) and spacers (ITS1) support the separation of the type species $(H$. perezi) from a currently unnamed second species (referred to as Hematodinium sp. in several recent publications [11-14,20,23]. Based on the rRNA sequences obtained from infected hosts, the parasite described herein infecting brown shrimp (C. crangon) from European waters also falls into the latter (Hematodinium sp.), despite the relatively close geographic existence between the field site utilized here and that of the recent description of the type species, $H$. perezi in $L$. depurator [11]. Recent studies have also suggested some level of host specificity within the Hematodinium sp. infecting hosts from the North Atlantic. Hamilton et al. [21] describe three distinct genotypic groups (based on Hematodinium sp ITS1 sequences) that correspond to hosts species rather than geographic location. However, in the current study the major Hematodinium sp. ITS1 allele from C. crangon was identical to those in GenBank from multiple hosts, including C. opilio, L. depurator, $N$. norvegicus, $P$. bernhar$d u s$, and others. Likewise, the minor and unique ITS1 alleles were also identical to ITS sequences from multiple hosts, or differed by a combination of SNPs and repetitive elements, respectively, suggesting no relationship between host species. An additional confounding factor is that the majority of recent studies reporting rRNA sequences from the Hematodinium sp. have utilized direct sequencing techniques $[7,13,21]$. Therefore, the ITS1 sequences deposited in GenBank may not represent the true allelic diversity of the Hematodinium sp. in a particular host.

The current description of Hematodinium sp. infection in Crangon crangon provides a further example host within the Infraorder Caridea (shrimp) and significantly, the first description within the superfamily Crangonoidea. Previously, Hematodinium perezi has been reported from a member of the superfamily Palaemonoidea (Exopalaemon carinicauda), co-cultured with the brachyuran crabs
(Portunus trituberculatus and S. Serrata) in China [1,4]. The infection of $P$. trituberculatus, S. Serrata, and E. carinicauda by $H$. perezi [4-6] provided the first examples of $H$. perezi as a potential problem in the global crustacean aquaculture industry, and suggests that this pathogen is capable of infecting novel species under polyculture conditions. This feature further reinforces the likelihood for low host specificity in this parasite genus $[7,8,13,20]$. Taken together, these data suggest that both known types (H. perezi and Hematodinium sp.) can infect different hosts residing in relative close proximity to one another, at least in waters including and adjacent to, the English Channel.

In the current study, we also report the presence of a bacteria-like endosymbiont within the Hematodinium sp. parasite infecting C. crangon. Despite numerous published studies which have provided detailed ultrastructural data relating to infections by both $H$. perezi [11] and Hematodinium sp. [6,15,22,24-27], similar endosymbiotic associations have not previously been observed. The bacteria-like endosymbionts occurred singly within electron lucent vacuoles, or in direct contact with the dinospore cytoplasm. In rare cases, they were also observed in direct contact with the dinospore nucleoplasm and also apparently undergoing fission. In no cases were obvious detrimental effects of colonization observed within the parasite cell. The presence of bacteria-like endosymbionts within spore life stages presumes that the endosymbiont may remain with the spore following its presumed liberation from the infected host shrimp. Ultrastructural analysis of free-living life stages of Hematodinium liberated to the water column following sporulation in crustaceans hosts [2,28] may elucidate whether bacterial endosymbionts play a role in dinospore survival in open water.

Endosymbiotic relationships such as that described here entail complementation of the host's metabolic capacity by that of the endosymbiont, possibly enabling the host to exist in previously unsuitable environments [29]. Several examples exist whereby dinoflagellates have been shown to harbour a range of prokaryotic and eukaryotic endosymbionts including alga [30,31] and bacteria, both within their cytoplasm [32] and even their nucleoplasm [33]. The most common forms of association relate to photosynthesis, nitrogen fixation or methanogenesis, although in the majority of cases, little more than a morphological description of the association is available [29]. Wilcox [32] proposes that although the nature of the association between the dinoflagellate and the bacteria is often enigmatic, both appear healthy, suggesting a stable 
relationship rather than a pathogenic one. Schweikert and Meyer [34], working on the freshwater dinoflagellate Peridinium cincture described colonisation by two previously undetected bacterial symbionts belonging to the eubacterial $\alpha$ - and $\gamma$-subgroups of proteobacteria. In this case, the bacterial symbionts maintained a stable association with the dinoflagellate in culture for over 2.5 years. In such instances, maintenance is suggestive of some benefit for the host cell. Regardless of the nature of the relationship between the bacteria-like endosymbiont and Hematodinium, the finding is the first of its kind in the Order Syndiniales and may suggest an element of mixotrophy in the life cycle of Hematodinium [35].

In other scenarios, algae (including the dinoflagellates) have been shown to be afflicted by a large number of bacterial pathogens which cause disease and impacts on fundamental properties of aquatic ecosystems [36]. Bacterial pathogens identified in alga to date include the Gramnegative genera Alteromonas, Cytophaga, Flavobacterium, Pseudomonas, Pseudoalteromonas, Saprospira and Vibrio. In addition to pathogenic effects on reef-building coralline algae, closely related bacteria also co-occur with pelagic bloom-forming microalgae such as dinoflagellates, and display potent algicidal properties [36]. These properties have even been exploited for mitigating the red tides formed by blooms of these algae [37].

\section{Conclusions}

The incorporation of bacteria by heterotrophic eukaryotes has been implicated in the establishment of reduced endosymbionts, functioning as cellular organelles (e.g. for photosynthesis) within the host cell. Genomic reduction within the endosymbiont which accompanies this acquisition then blurs the distinction between 'endosymbiont' and 'organelle' [29]. Clearly in the case of Hematodinium, we know little of the nature of the association between the bacteria-like endosymbiont and the parasite in crangonid shrimp. Nevertheless, the finding offers a further intriguing insight into the life history of this enigmatic pathogen. Further effort is now required to identify the endosymbiont and to investigate the nature of its relationship with Hematodinium.

\section{Methods}

Collection of specimens and processing for histology and electron microscopy

Brown shrimp (Crangon crangon) were collected in July 2010 during the annual Clean Seas Environmental Monitoring Programme (CSEMP) survey of United Kingdom marine waters. Shrimp were specifically collected from sites within the Wash, North Sea (53.1417 N, 0.555 W). Upon capture, animals were placed live onto large trays for visual health assessments. During sorting, abnormal looking animals with an opaque carapace and apparently milky consistency of the haemolymph and underlying tissues were removed from the catch for processing (Figure 1). Representative examples of externally normal shrimp and those displaying signs of opacity were chilled on ice prior to dissection.

For histopathology, the hepatopancreas, gills, heart, midgut, gonad and skeletal muscles were dissected from each specimen. Excised samples were placed immediately into Davidson's seawater fixative. Fixation was allowed to proceed for $24 \mathrm{~h}$ before samples were transferred to $70 \%$ industrial methylated spirit for storage prior to processing. Fixed samples were processed to wax in a vacuum infiltration processor using standard protocols. Sections were cut at a thickness of 3 to $5 \mu \mathrm{m}$ on a rotary microtome and were mounted onto glass slides before staining with haematoxylin and eosin (HE). Stained sections were analysed by light microscopy (Nikon Eclipse E800) and digital images were taken using the Lucia ${ }^{\text {Tx }}$ Screen Measurement System (Nikon).

For electron microscopy, $2 \mathrm{~mm}^{3}$ blocks of skeletal muscle and hepatopancreas were fixed in a solution containing $2.5 \%$ glutaraldehyde in $0.1 \mathrm{M}$ sodium cacodylate buffer ( $\mathrm{pH} 7.4$ ), for $2 \mathrm{~h}$ at room temperature prior to rinsing in $0.1 \mathrm{M}$ sodium cacodylate buffer with $1.75 \%$ sodium chloride ( $\mathrm{pH} 7.4)$ and post-fixation in $1 \%$ osmium tetroxide in $0.1 \mathrm{M}$ sodium cacodylate buffer for $1 \mathrm{~h}$ at $4^{\circ} \mathrm{C}$. Specimens were washed in three changes of $0.1 \mathrm{M}$ sodium cacodylate buffer and dehydrated through a graded acetone series. Specimens were embedded in Agar 100 epoxy resin (Agar Scientific, Agar 100 pre-mix kit medium) and polymerised overnight at $60^{\circ} \mathrm{C}$ in an oven. Semi-thin $(1-2 \mu \mathrm{m})$ sections were stained with Toluidine Blue for viewing with a light microscope to identify suitable target areas. Ultrathin sections $(70-90 \mathrm{~nm})$ of target areas were mounted on uncoated copper grids and stained with $2 \%$ aqueous uranyl acetate and Reynolds' lead citrate. Grids were examined using a JEOL JEM 1210 transmission electron microscope and digital images captured using a Gatan Erlangshen ES500W camera and Gatan Digital Micrograph ${ }^{\text {Tw }}$ software.

For molecular analysis, gill and hepatopancreas samples corresponding to those regions sampled for histology and electron microscopy were dissected and placed directly into $100 \%$ ethanol. Genomic DNA was subsequently extracted from these tissues from C. crangon histologically identified as having Hematodinium sp. Infections. Tissue was weighed and homogenized in G2 buffer and proteinase K (Qiagen), using a Fastprep ${ }^{\text {Tw }}$ tissue disruptor (MP Biomedicals), to give a $10 \% \mathrm{w} / \mathrm{v}$. DNA was extracted from a $50 \mu \mathrm{l}$ volume of the homogenate using the EZ1 DNA Tissue kit (Qiagen) and the BioRobot EZ1 workstation (Qiagen), following the manufacturer's protocol. DNA was eluted in $50 \mu \mathrm{l}$ buffer and stored at $-20^{\circ} \mathrm{C}$ prior to use in PCR assays. The 3' end of the SSU rRNA gene and the 
first internal transcribed spacer (ITS1) region of the Hematodinium sp. infecting C. crangon were amplified from six genomic DNA samples (isolated from separate shrimp) using the forward and reverse primer pairs A (5'-GTTCCCCTTGAACGAGGAATTC-3') and B (5'- CGCATTTCGCTGCGTTCTTC-3') from Hudson and Adlard (1994). Amplification reactions were carried out in a DNA Engine Tetrad 2 (MJ Research) and contained approximately $100 \mathrm{ng}$ genomic DNA, 1x Green GoTaq Flexi Buffer (Promega), $2.5 \mathrm{mM} \mathrm{MgCl}_{2}, 0.25 \mathrm{mM}$ of each dNTP, $0.5 \mu \mathrm{M}$ of each primer, 1.25 units GoTaq DNA polymerase and molecular grade water to a final volume of $50 \mu \mathrm{l}$. Reactions were overlaid with oil and 30 cycles of the following carried out: denaturation at $94^{\circ} \mathrm{C}$ for $1 \mathrm{~min}$; primer annealing at $55^{\circ} \mathrm{C}$ for $30 \mathrm{~s}$; extension at $72^{\circ} \mathrm{C}$ for $90 \mathrm{~s}$, followed by a final $7 \mathrm{~min}$ extension.

PCR products were resolved on a $2 \%(\mathrm{w} / \mathrm{v})$ agarose/TAE (40 mM Tris acetate, pH7.2, 1 mM EDTA) gel containing $0.625 \mathrm{mg} / \mathrm{ml}$ ethidium bromide and viewed under UV light. Gel fragments of approximately $680 \mathrm{bp}$ were excised and purified using the Wizard ${ }^{\mathbb{B}}$ SV Gel and PCR Clean-Up System (Promega). Purified amplification products were ligated into the $\mathrm{pGEM}^{\mathbb{B}}$-T cloning vector (Promega) and plasmid inserts were bi-directionally sequenced using the amplification primers (A and B) and BigDye ${ }^{\circledR}$ Terminator v3.1 Cycle Sequencing Kit (Applied Biosystems), following the manufacturer's protocol. Sequencing reactions were electrophoresed on an ABI 3130xl Genetic Analyzer (Applied Biosystems). For each of the six genomic C. crangon DNA samples amplified, five clones were sequenced bi-directionally. Hematodinium spp. sequences were constructed from the forward and reverse sequencing reactions using Sequencher (version 4.1.4). Primer sequences and regions of poor resolution were removed from the $5^{\prime}$ and 3 'regions, and the borders of flanking SSU and 5.8S RNA genes identified by comparison with sequences from previous studies $[12,14]$. The resulting partial SSU and ITS1 sequences obtained were compared for similarity to other Hematodinium spp. sequences in GenBank using the Basic Local Alignment Search Tool (BLAST) function [38]. The partial SSU and complete ITS1 rRNA sequences from the Hematodinium sp. infecting $C$. crangon have been deposited in GenBank with accession numbers JX499154- JX499183.

\section{Competing interests}

The authors declare that they have no competing interests.

\section{Authors' contributions}

GDS was responsible for initial discovery of the pathogen, pathology and ultrastructural work and initial drafting of the manuscript. KSB was responsible for initial fieldwork, pathology and ultrastructural analysis of the pathogen. MP and AU were responsible for molecular diagnostics (PCR and sequencing) and for providing appropriate text to the manuscript. HJS was responsible for overseeing molecular phylogenetic assessments and for providing text to the manuscript. All authors read and approved the final manuscript.
Authors' information

GDS is Director of the European Union Reference Laboratory for Crustacean Diseases.

\section{Acknowledgements}

The authors acknowledge support from the UK Department for Environment, Food and Rural Affairs (Defra) under contract SLA24 for the opportunity to collect specimens aboard the RV Cefas Endeavour. Furthermore, to the European Commission under contract C5202 (to GDS) and the UK Department for Environment, Food and Rural Affairs (Defra) under contract FB002 (to GDS) for all laboratory analyses. HJS was supported by grant OCE BE-UF0723662 from the National Science Foundation of the USA.

\section{Author details}

${ }^{1}$ European Union Reference Laboratory for Crustacean Diseases, Centre for Environment, Fisheries and Aquaculture Science (Cefas), Barrack Road, Weymouth, Dorset DT4 8UB, United Kingdom. ${ }^{2}$ Virginia Institute of Marine Science, College of William and Mary, P.O. Box 1346, Gloucester Point, VA 23062, USA. ${ }^{3}$ Department of Biology and Environmental Sciences, Tjärnö, University of Gothenburg, Strömstad, SE 452 96, Sweden.

Received: 31 May 2012 Accepted: 16 August 2012

Published: 7 September 2012

\section{References}

1. Small HJ: Advances in our understanding of the global diversity and distribution of Hematodinium spp. - Significant pathogens of commercially exploited crustaceans. I Invert Pathol 2012, 110:234-246.

2. Stentiford GD, Shields JD: A review of the parasitic dinoflagellates Hematodinium species and Hematodinium-like infections in marine crustaceans. Dis Aquat Org 2005, 66:47-70.

3. Morado JF: Protistan diseases of commercially important crabs: A review. J Invertebr Pathol 2011, 106:27-53.

4. Xu W-J, Xie J, Shi H, Li C: Hematodinium infections in cultured ridgetail white prawns, Exopalaemon carinicauda, in eastern China. Aquaculture 2010, 300:25-31.

5. Xu W-J, Shi H, Xu H-X, Small HJ: Preliminary study on the Hematodinium infection in cultured Portunus trituberculatus. Acta Hydrobiol Sin 2007, 31:640-647.

6. Li YY, Xia XA, Wu QY, Liu WH, Lin YS: Infection with Hematodinium sp. in mud crabs Scylla serrata cultured in low salinity water in southern China. Dis Aquat Org 2008, 82:145-150.

7. Eigemann F, Burmeister A, Skovgaard A: Hematodinium sp. (Alveolata, Syndinea) detected in marine decapod crustaceans from waters of Denmark and Greenland. Dis Aquat Org 2010, 92:59-68.

8. Pagenkopp Lohan KM, Reece KS, Miller TL, Wheeler KN, Small HJ, Shields JD: The role of alternate hosts in the ecology and life history of Hematodinium sp. a parasitic dinoflagellate of the blue crab (Callinectes sapidus). J Parasitol 2012, 98:73-84.

9. Johnson PT: Parasites of benthic amphipods: dinoflagellates (Duboscquodinida: Syndinidae). Fish Bull 1986, 84:605-614

10. Small HJ, Neil DM, Taylor AC, Atkinson RJA, Coombs GH: Molecular detection of Hematodinium spp. in Norway lobsters, Nephrops norvegicus, and other crustaceans. Dis Aquat Org 2006, 69:18-195.

11. Small HJ, Reece KS, Shields JD, Bateman K, Stentiford GD: Morphological and molecular characterization of Hematodinium perezi (Dinophyceae: Syndiniales), a dinoflagellate parasite of the harbour crab, Liocarcinus depurator. J Eukaryot Microbiol 2012, 59:54-66.

12. Hudson DA, Adlard RD: Nucleotide sequence determination of the partial SSU rDNA gene and ITS1 region of Hematodinium cf. perezi and Hematodinium-like dinoflagellates. Dis Aquat Org 1996, 24:55-60.

13. Jensen PC, Califf K, Lowe V, Hauser L, Morado JF: Molecular detection of Hematodinium sp. in Northeast Pacific Chionoecetes spp. and evidence of two species in the Northern Hemisphere. Dis Aquat Org 2010, 89:15-166.

14. Small HJ, Shields JD, Hudson KL, Reece KS: Molecular detection of Hematodinium sp. infecting the blue crab Callinectes sapidus. J Shellfish Res 2007a, 26:131-139.

15. Field RH, Chapman CJ, Taylor AC, Neil DM, Vickerman K: Infection of the Norway lobster Nephrops norvegicus by a Hematodinium-like species of dinoflagellate on the West Coast of Scotland. Dis Aquat Org 1992, 13:1-15. 
16. Latrouite D, Morizur Y, Noël P, Chagot D, Wilhelm G: Mortalite du tourteau Cancer pagurus provoquee par le dinoflagelle parasite: Hematodinium sp. Conseil International pour l'Exploration de la Mer, CM 1988, 32.

17. Stentiford GD, Green M, Bateman K, Small HJ, Neil DM, Feist SW: Infection by a Hematodinium-like parasitic dinoflagellate causes Pink Crab Disease (PCD) in the edible crab Cancer pagurus. J Invertebr Pathol 2002, 79:179-191.

18. Stentiford GD, Bateman K, Feist SW: Pathology and ultrastructure of an intranuclear bacilliform virus (IBV) infecting brown shrimp Crangon crangon (Decapoda: Crangonidae). Dis Aquat Org 2004, 58:89-87.

19. Stentiford GD, Feist SW: A histopathological survey of shore crab (Carcinus maenas) and brown shrimp (Crangon crangon) from six estuaries in the United Kingdom. J Invertebr Pathol 2005, 88:136-146.

20. Small HJ, Shields JD, Moss JA, Reece KS: Conservation in the first internal transcribed spacer region (ITS1) in Hematodinium species infecting crustacean hosts found in the UK and Newfoundland. Dis Aquat Org 2007, 75:251-258.

21. Hamilton KM, Morritt D, Shaw PW: Genetic diversity of the crustacean parasite Hematodinium (Alveolata, Syndinea). Eur J Protistol 2010, 46:17-28.

22. Stentiford GD, Neil DM, Peeler EJ, Shields JD, Small HJ, Flegel TW, Vlak JM, Jones B, Morado F, Moss S, Lotz J, Bartholomay L, Behringer DC, Hauton C, Lightner DV: Disease will limit future food supply from the global crustacean fishery and aquaculture sectors. J Invert Pathol 2012, 110:141-157.

23. Hamilton KM, Morritt D, Shaw PW: Molecular and histological identification of the crustacean parasite Hematodinium (Alveolata, Syndinea) in the shore crab Carcinus maenas. Acta Protozool 2007, 46:183-192.

24. Meyers TR, Koeneman TM, Botelho C, Short S: Bitter crab disease: a fatal dinoflagellate infection and marketing problem for Alaskan Tanner crabs Chionoecetes bairdi. Dis Aquat Org 1987, 3:195-216.

25. Hudson DA, Shields JD: Hematodinium australis n.sp., a parasitic dinoflagellate of the sand crab Portunus pelagicus from Moreton bay, Australia. Dis Aquat Org 1994, 19:109-119.

26. Messick GA: Hematodinium perezi infections in adult and juvenile blue crabs Callinectes sapidus from coastal bays of Maryland and Virginia, USA. Dis Aquat Org 1994, 19:77-82.

27. Stentiford GD, Neil DM: Diseases of Nephrops and Metanephrops: a review. J Invertebr Pathol 2011, 106:92-109.

28. Frischer ME, Lee RF, Sheppard MA, Mauer A, Rambow F, Neumann M, Brofft JE, Wizenmann T, Danforth JM: Evidence for a free-living life stage of the blue crab parasitic dinoflagellate, Hematodinium sp. Harmful Algae 2006, 5:548-557.

29. Nowack ECM, Melkonian M: Endosymbiotic associations within protists. Phil Trans R SoC B 2010, 365:699-712.

30. Tomas RN, Cox ER: Observations on the symbiosis of Perktinium balticum and its intracellular alga I. Ultrastructure. J. Phycol 1973, 9:304-323.

31. Wilcox LW, Wedemayer GJ: Gymnodinium acidotum Nygaard (Pyrrophyta), a dinoflagellate with an endosymbiotic cryptomonad. J. Phycol. 1984, 20:236-242.

32. Wilcox LW: Prokaryotic endosymbionts in the chloroplast stroma of the dinoflagellate Woloszynskia pascheri. Protoplasma 1986, 135:71-79.

33. Silva ES: Endonuclear bacteria in two species of dinoflagellates. Protistologica 1978, 14:113-119.

34. Schweikert M, Meyer B: Characterization of intracellular bacteria in the freshwater dinoflagellate Peridinium cincture. Protoplasma 2001, 217:177-184

35. Stoecker DK: Mixotrophy among dinoflagellates. J Eukary Microbiol 1999, 46:397-401.

36. Gachon CMM, Telesphore S-N, Strittmatter M, Chambouvet A, Kim GH: Algal diseases: spotlight on a black box. Trends Plant Sci 2010, 15:633-640.

37. Kim D, Kim JF, Yim JH, Kwon SK, Lee CH, Lee HK: Red to red - the marine bacterium Hahella chejuensis and its product prodigiosin for mitigation of harmful algal blooms. J Microbiol Biotechnol 2008, 18:1621-1629.

38. Altschul SF, Gish W, Miller W, Myers EW, Lipman DJ: Basic local alignment search tool. J Mol Biol 1990, 215:403-410.

doi:10.1186/2046-9063-8-24

Cite this article as: Stentiford et al:: Hematodinium sp. and its bacteria-

like endosymbiont in European brown shrimp (Crangon crangon).

Aquatic Biosystems 2012 8:24.

\section{Submit your next manuscript to BioMed Central and take full advantage of:}

- Convenient online submission

- Thorough peer review

- No space constraints or color figure charges

- Immediate publication on acceptance

- Inclusion in PubMed, CAS, Scopus and Google Scholar

- Research which is freely available for redistribution 